\title{
Efectos de medicamentos homeopáticos en indicadores fisiológicos y del desarrollo inicial del frijol Yorimón (Vigna unguiculata L., Walp.) Effects of homeopathic medicines on physiological indicators and the initial development of Yorimón bean (Vigna unguiculata L., Walp.)
}

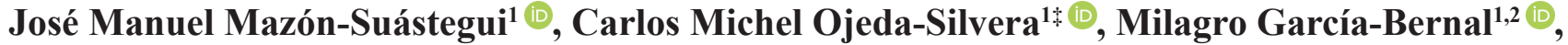

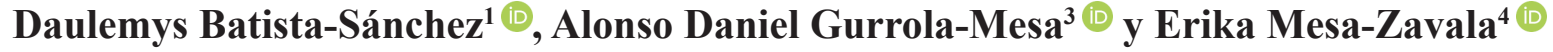

\footnotetext{
${ }^{1}$ Centro de Investigaciones Biológicas del Noroeste S.C. Av. I. P. N. no. 195, Colonia Playa Palo de Santa Rita Sur. 23096 La Paz, Baja California Sur, México. *Autor para correspondencia / Corresponding author (cojedas1979@gmail.com)

${ }^{2}$ Universidad Central de las Villas (CBQ). Carretera a Camajuaní km 5.5. Santa Clara, Provincia de Villa Clara, Cuba.

${ }^{3}$ Colegio María Fernanda. Melitón Albáñez 3280, Las Garzas. 23079 La Paz, Baja California Sur, México.

${ }^{4}$ Universidad Mundial. Mariano Abasolo s/n, Pueblo Nuevo. 23090 La Paz, Baja California Sur, México.
}

\section{RESUMEN}

La medicina homeopática es una disciplina de la ciencia médica universal, con aplicación creciente en humanos, animales y plantas. La aceptación de la homeopatía agrícola se incrementa por la inocuidad y probada efectividad de sus medicamentos ultradiluidos y agitados, para estimular la germinación, crecimiento, desarrollo y producción de varias especies vegetales. El presente trabajo tuvo como objetivo evaluar el efecto de medicamentos homeopáticos en indicadores fisiológicos y del desarrollo, en frijol Yorimón (Vigna unguiculata L., Walp.) var. Paceña. Se usó un diseño completamente al azar con dos tratamientos homeopáticos, Manganum metallicum 31CH (MnM31CH), Magnesium-manganum phosphoricum $3 \mathrm{CH}$ (MaMnP-3CH) y como tratamiento control agua destilada (AD), con seis réplicas por tratamiento. Se evaluó tasa fotosintética, transpiración, clorofila total, área foliar y biomasa fresca y seca de raíz, tallo y hojas. Se aplicó un análisis de varianza y cuando hubo diferencia significativa entre tratamientos, una comparación de medias (Tukey HSD, $P \leq 0.05$ ). Los resultados revelaron un incremento significativo para todas las variables evaluadas con respecto al tratamiento control (AD), en las plantas que recibieron tratamientos homeopáticos (MnM-31CH y MaMnP-3CH). La biomasa fresca de raíz fue la variable de respuesta con mayor incremento porcentual (111.2\%) y se registró en

Cita recomendada / Recommended citation:

Mazón-Suástegui, J. M., C. M. Ojeda-Silvera, M. García-Bernal, D. Batista-Sánchez, A. D. Gurrola-Mesa y E. Mesa-Zavala. 2020. Efectos de medicamentos homeopáticos en indicadores fisiológicos y del desarrollo inicial del frijol Yorimón (Vigna unguiculata L., Walp.). Terra Latinoamericana Número Especial 38-1: 125-135.

DOI: https://doi.org/10.28940/terra.v38i1.581

\section{SUMMARY}

Homeopathic medicine is a discipline of universal medical science, with increasing application in humans, animals and plants. The acceptance of agricultural homeopathy is increased by the safety and proven effectiveness of its ultra-diluted and agitated medicines, to stimulate the germination, development, growth and production of various plant species. The present work aimed to evaluate the effect of homeopathic medicines on physiological indicators and the development of Yorimón beans (Vigna unguiculata L., Walp.) var. Paceña. A completely randomized design was used with two homeopathic treatments, Manganum metallicum 31CH (MnM31CH), Magnesium-manganum phosphoricum $3 \mathrm{CH}$ (MaMnP-3CH) and as a control treatment destilled water (DW), with six replicas per treatment. Photosynthetic rate, perspiration, total chlorophyll, leaf area and fresh and dried biomass of root, stem and leaves were evaluated. An analysis of variance was applied and when there was a significant difference between treatments, a comparison of means (Tukey HSD, $P \leq 0.05)$. The results revealed a significant increase for all the variables evaluated with respect to the control treatment (DW), in the plants that received treatments (MnM-31CH and MaMnP-3CH). Fresh root biomass was the response variable with the highest percentage increase $(111.2 \%)$ and was recorded in

Recibido / Received: julio / July 02, 2019. Aceptado / Accepted: diciembre / December 04, 2019. Publicado en / Published in Terra Latinoamericana 38: 125-135. 
las plantas tratadas con MnM-31CH, comparado con las plantas del grupo control, sin medicación homeopática (AP). Igualmente, en las plantas tratadas (MnM-31CH y MaMnP-3CH) se registró un incremento superior al $40 \%$ en clorofila total y en fotosíntesis. Esto confirma la efectividad de los tratamientos aplicados y el potencial de la homeopatía agrícola para incrementar eficiencia en el cultivo de $V$. unguiculata.

Palabras clave: clorofila, fotosíntesis, homeopatía agrícola, producción de biomasa.

\section{INTRODUCCIÓN}

El frijol es un cultivo de gran importancia en el mundo como leguminosa de grano y como hortaliza. La mayor parte de su producción tiene lugar en países en vía de desarrollo y es una de las fuentes primarias y más baratas de calorías, proteínas, fibra dietética, vitaminas y minerales para consumo humano en esos países (Hillocks et al., 2006). El frijol es complementario de cereales y de otros alimentos ricos en carbohidratos para proporcionar una nutrición casi perfecta para personas de todas las edades, disminuyendo además el colesterol y el riesgo de padecer cáncer (Muhamba y Nchimbi, 2010). Estudios arqueológicos revelan que el frijol se originó en el continente americano, ya que existen evidencias con antigüedad de 500 a 8 mil años en algunas regiones de México, Estados Unidos y Perú. Existe un relativo acuerdo respecto a que el frijol es originario de México y de ahí se diseminaron las primeras semillas hacia el sur del continente americano, porque es posible encontrar prototipos de especies silvestres de las cinco especies más cultivadas del género Phaseolus. Sin embargo, otras fuentes estiman que esta leguminosa se domesticó y se cultivó antes de la época precolombina (García, 2005) y que, a través de la selección natural, se habrían generado diferentes tipos de semillas (Debouck e Hidalgo, 1985). Fue tal la importancia adquirida por el frijol en esa época, que la civilización azteca llegó a incluirlo en la lista de artículos que debían cobrarse como tributo a otras tribus de menor poderío, por el aprovechamiento de los recursos naturales o de los sitios en los que esas tribus se establecían y habitaban, dentro de los límites del imperio azteca (Voysest, 2000).

El frijol es un cultivo clave en la dieta nacional de México, pero a pesar de su alto consumo y de haber experimentado un ligero incremento en el año 2017 the plants treated with $\mathrm{MnM}-31 \mathrm{CH}$, compared to the plants in the control group, without medication (DW). Likewise, in the treated plants (MnM-31CH and $\mathrm{MaMnP}-3 \mathrm{CH})$ there was an increase greater than $40 \%$ in total chlorophyll and in photosynthesis. This confirms the effectiveness of applied treatments and reveals potential of agricultural homeopathy, as an alternative to achieve greater efficiency in the cultivation of $V$. unguiculata.

Index words: chlorophyll, photosynthesis, agricultural homeopathy, biomass production.

\section{INTRODUCTION}

Beans are a greatly important cultivation worldwide both as grain legume and vegetable. The greatest part of their production takes place in developing countries, and they are one of the cheapest main sources of calories, proteins, dietary fiber, vitamins and minerals for human consumption in those countries (Hillocks et al., 2006). Beans are supplements of cereals and other food rich in carbohydrate to provide an almost perfect nutrition for people of all ages besides decreasing cholesterol and the risk of cancer (Muhamba and Nchimbi, 2010). Archeological studies have revealed that beans originated in the American continent since 500-8000 year-old evidence exists in some regions of Mexico, the United States and Peru. A relative agreement exists with respect to the fact that beans originated in Mexico and from there the first seeds spread out toward the southern part of the American continent because it is possible to find wild prototype species of the five most cultivated ones of the genus Phaseolus. Nevertheless, other sources estimate that this legume was domesticated and cultivated before the PreColumbian era (García, 2005), which through natural selection different types of seeds generated (Debouck and Hidalgo, 1985). Such was the importance acquired by beans at that time, that Aztec civilization included them in the list of articles that should be collected as tribute from other tribes less powerful for taking advantage of the natural resources or the sites where these tribes were established or inhabited within the limits of the Aztec Empire (Voysest, 2000).

Beans are a key cultivation in the national Mexican diet, but despite their high consumption and having experimented a slight increase in 2017 with 
con respecto al año anterior (SIAP, 2018), actualmente su producción no suple los niveles de demanda del país. La baja productividad de este importante cultivo se atribuye a factores ambientales adversos, pero de manera predominante, a la presencia de organismosplaga y a diversas enfermedades asociadas a patógenos bacterianos y virales que no le permiten alcanzar su potencial productivo (Bolaños et al., 2009). Como resultado de esta sinergia de factores limitativos bióticos y abióticos, en la actualidad, este cultivo milenario no produce los rendimientos deseados para suplir la alta demanda que tiene, siendo cada vez más necesaria la búsqueda de alternativas que permitan superar esas limitaciones y aprovechar su gran potencial.

A la fecha, las investigaciones encaminadas hacia ese objetivo se han dirigido a la aplicación de biofertilizantes para hacer más eficiente su ciclo vegetativo, reduciendo la fertilización inorgánica con agroquímicos y los impactos negativos que conlleva su uso al medio ambiente (Estrada-Prado et al., 2018). También se han realizado estudios sobre el uso de abonos verdes y asociaciones con otros cultivos para mejorar la fertilidad del suelo, el contenido de nutrientes en las plantas y su efecto en la producción de biomasa (Rivero-Herrada et al., 2016). Otra línea de investigación con tendencia creciente durante los últimos años es la aplicación de bioestimulantes naturales con capacidad para vigorizar a las plantas y lograr mayores producciones (Moreno-Lorenzo et al., 2018; Calero-Hurtado et al., 2019). Finalmente, una alternativa eco-amigable de aplicación reciente y con alta posibilidad de éxito debido a la inocuidad de sus productos y viabilidad económica, es la aplicación de medicamentos homeopáticos autorizados para uso en humanos, con registro en instituciones of iciales como la Secretaría de Salud de México (SSA, 2015). Se comprobó que estos medicamentos tienen la capacidad de inducir respuestas biológicas que favorecen el crecimiento y desarrollo de diversas especies vegetales (Mazón-Suástegui et al., 2018, 2019), permitiendo obtener plantas más vigorosas con mayor rendimiento en biomasa y, por ende, con mayor potencial y rentabilidad económica en su cultivo. Existen evidencias científicas del uso de productos homeopáticos en plantas y su efecto benéfico, en la estimulación del crecimiento y producción de biomasa, sustentado en la acción directa de los ingredientes activos en los procesos fisiológicos de las plantas tratadas con homeopatía (Meneses-Moreno, 2017). También se demostró respect to the previous year (SIAP, 2018), currently, its production does not supply the levels of demand in the country. The low productivity of this important cultivation is attributed to adverse environmental factors, but predominantly to the presence of pestorganisms and diverse diseases associated to bacterial and viral pathogens that do not allow them to reach their productive potential (Bolaños et al., 2009). As a result of the biotic and abiotic factor synergy, currently, this millennial cultivation does not produce the expected yield to supply its high demand, which has increased the need of searching for alternatives to overcome these limitations and take advantage of its great potential.

To date, research aimed at this objective has focused on biofertilizers to make their vegetative cycle more efficient, reducing inorganic fertilization with agrochemicals and the negative impacts their use implies affecting the environment (EstradaPrado et al., 2018). Additionally, studies have been performed on the use of green fertilizer and associations with other cultivations to improve soil fertility, nutrient content and their effect in biomass production (Rivero-Herrada et al., 2016). Another line of research with growing tendency in the last years is the application of natural bio-stimulants with the capacity of strengthening plants and achieving greater productions (Moreno-Lorenzo et al., 2018; Calero-Hurtado et al., 2019). Finally, an ecofriendly alternative of recent application and a high possibility of success due to the innocuousness of its products and economic viability is the application of homeopathic medicines authorized for use in humans with registration in official institutions, such as the Health Ministry of México (SSA, 2015). These highly diluted and low-cost medicines, have proven the capacity of inducing biological responses that favor growth and development of diverse plant species (Mazón-Suástegui et al., 2018, 2019), allowing to obtain more vigorous plants with greater yield in biomass and thus with greater potential and economic feasibility in their cultivation. Scientific evidence of using homeopathic medicines in plants and their beneficial effects on stimulating growth and biomass production has been based on the direct action of the active ingredients on the physiological processes of the treated plants (Meneses-Moreno, 2017). Moreover, homeopathic medicines have demonstrated to strengthen plants allowing a better development, 
que los medicamentos homeopáticos vigorizan a las plantas permitiendo que se desarrollen mejor, incluso en ambientes desfavorables, como el estrés biótico y abiótico (Oliveira et al., 2014; Mazón-Suástegui et al., 2018). Por tal razón, el presente estudio tuvo como objetivo evaluar el efecto de medicamentos homeopáticos en indicadores fisiológicos y del desarrollo del frijol Yorimón (Vigna unguiculata L., Walp) variedad Paceña.

\section{MATERIALES Y MÉTODOS}

La investigación se realizó en el Campo Agrícola Experimental (CAE) del Centro de Investigaciones Biológicas del Noroeste, S.C. (CIBNOR) localizado al noroeste de la Ciudad de La Paz, B.C.S., México, a los $24^{\circ} 08^{\prime} 10.03^{\prime \prime} \mathrm{N}$ y $110^{\circ} 25^{\prime} 35.31^{\prime \prime} \mathrm{O}$, a $7 \mathrm{~m}$ de altitud. Los trabajos experimentales se llevaron a cabo en ambiente semicontrolado, bajo una estructura metálica totalmente cubierta con malla antiáfidos de color blanco con $30 \%$ de sombra, a temperatura mínima, media y máxima de $14.25 \pm 3.83,27.64 \pm 4.01,45.17 \pm 2.94{ }^{\circ} \mathrm{C}$, respectivamente, con humedad relativa de $34.8 \pm 5.07 \%$. Estos datos climatológicos se registraron con una estación climatológica portátil (Vantage Pro2® Davis Instruments, USA) dentro del área de estudio. Se aplicó un diseño experimental completamente al azar, con dos tratamientos homeopáticos, Manganum metallicum 31CH (MnM-31CH), Magnesium-manganum phosphoricum 3CH (MaMnP-3CH) y agua destilada como tratamiento control (AD), con seis réplicas por cada tratamiento. Las semillas se desinfectaron previo a la siembra con una solución de hipoclorito de sodio $1.5 \%$ y se realizó una prueba de germinación según la metodología del ISTA (2010).

Las semillas se sembraron en macetas de plástico con capacidad de un litro con sustrato comercial inerte $\left(\right.$ Sogemix $\mathrm{PM}^{\circledR}$ ) y se aplicaron riegos diarios hasta lograr la saturación del sustrato, con agua y solución nutritiva calculada y ajustada para el cultivo de $V$. unguiculata, tomando como base las instrucciones del manual para soluciones nutritivas de Samperio (1997). Las diluciones homeopáticas (MnM-31CH, MaMnP-3CH) y el tratamiento control (AD) se asperjaron sobre las hojas en días alternos durante todo el experimento (50 días). A los 14 días de la siembra se inició la medición de tasa fotosintética y transpiración, en hojas completamente turgentes $\mathrm{y}$ sanas, en días soleados y en horario de mayor radiación including in unfavorable environments, such as those producing abiotic and biotic stress (Oliveira et al., 2014; Mazón-Suástegui et al., 2018). Therefore, the objective of this study was to assess the effect of homeopathic medicines in physiological markers in "Yorimon" cowpea bean (Vigna unguiculata L., Walp) variety Paceña.

\section{MATERIALS AND METHODS}

Research was performed in the Campo Agrícola Experimental (CAE, Experimental Agricultural Field) of Centro de Investigaciones Biológicas del Noroeste (CIBNOR) located northwest of the city of La Paz, Baja California Sur, México, at $24^{\circ} 08^{\prime} 10.03$ " N and $110^{\circ} 25^{\prime} 35.31 " \mathrm{~W}$, at $7 \mathrm{~m}$ altitude. The experimental study was performed in a semi-controlled environment under a metallic structure completely covered with a white $30 \%$ shade anti-aphid mesh, with a minimum, average, and maximum temperatures of $14.25 \pm 3.83$, $27.64 \pm 4.01,45.17 \pm 2.94{ }^{\circ} \mathrm{C}$, respectively, with relative humidity of $34.8 \pm 5.07 \%$. These climatological data were recorded with portable climatologic station (Vantage Pro2 ${ }^{\circledR}$ Davis Instruments, USA) within the area of study. A completely randomized design was applied with two homeopathic treatments, Manganum metallicum $31 \mathrm{CH} \quad(\mathrm{MnM}-31 \mathrm{CH})$, Magnesiummanganum phosphoricum 3CH (MaMnP-3CH), and distilled water (AD) as control treatment with six replicates per treatment. Seeds were disinfected previous to sowing with a $1.5 \%$ sodium hypochlorite solution, and a germination assay was performed according to the methodology of the International Seed Testing Association (ISTA, 2010).

Seeds were sown in plastic pots with $1 \mathrm{~L}$ capacity of inert commercial substrate $\left(\right.$ Sogemix $\mathrm{PM}^{\circledR}$ ); daily irrigation was applied until substrate saturation with water was reached and nutritional solution calculated and adjusted for the cultivation of $V$. unguiculata, based on the manual instructions for nutritional solutions of Samperio (1997). Homeopathic dilutions (MnM$31 \mathrm{CH}, \mathrm{MaMnP}-3 \mathrm{CH}$ ) and the control (AD) treatments were sprayed on leaves every other day during all the experiment (total of 50 days). Measurements started at day14 of sowing; photosynthetic and transpiration rates were taken from leaves completely turgid and healthy in sunny days and at the time of greater solar radiation (two times a week) using an IRGA 
solar (dos veces por semana), empleando un equipo (IRGA) LCpro-SD Portable Photosynthesis System que incluye una cámara broad-leaf (ADC, Hoddesdon, Herts, UK). La determinación de clorofila se realizó en cada planta, tomando muestras en hojas frescas y totalmente expandidas, previamente limpiadas con agua desionizada para remover cualquier contaminación ambiental en su superficie. Para la extracción de pigmentos fotosintéticos, se tomó $1 \mathrm{~g}$ de material fresco por muestra, el cual se trituró en mortero con acetona al 90\%, dejando reposar posteriormente en la oscuridad por $72 \mathrm{~h}$, antes de medir absorbancia a $663 \mathrm{y}$ $645 \mathrm{~nm}$ de longitud de onda, con un espectrofotómetro con UV/Visible spectrophotometer (Pye Unicam SP6$550, \mathrm{UK})$.

A los 50 días posteriores a la siembra, se evaluó el área foliar $\left(\mathrm{cm}^{2}\right)$ con un equipo integrador de área foliar (Li-Cor ${ }^{\circledR}$, modelo-LI-3000A, serie PAM 1701USA). La biomasa fresca ( $\mathrm{g})$, se determinó mediante el pesaje de raíz (BFR), de tallo (BFT) y hoja (BFH), en una balanza analítica (Mettler Toledo ${ }^{\circledR}$, modelo AG204 USA). Para obtener la biomasa seca, se colocó todo el material fresco por separado (raíz, tallo y hojas) en bolsas de papel, y se introdujo en una estufa de secado $\left(\right.$ Shel-Lab $^{\circledR}$, modelo FX-5, serie-1000203) a $70{ }^{\circ} \mathrm{C}$ durante $72 \mathrm{~h}$ para su total deshidratación y al final de este proceso se pesaron en balanza analítica (Mettler Toledo ${ }^{\circledR}$, AG204) expresando el valor en gramos. Se realizó un análisis de varianza y cuando se encontró diferencia significativa entre tratamientos, se aplicó la prueba de comparación múltiple de medias Tukey HSD, $P \leq 0.05$, utilizando el programa estadístico Statistica v. 10.0 para Windows (StatSoft, Inc, 2011).

\section{RESULTADOS Y DISCUSIÓN}

Los resultados del análisis de clorofila total y tasa fotosintética mostraron diferencias significativas $(P=0.02)$ entre tratamientos, con incremento en la concentración de pigmentos fotosintéticos en las plantas que recibieron tratamientos homeopáticos. Esta diferencia fue superior a $90 \%$ en las plantas que recibieron una dinamización homeopática 31 Centesimal Hahnemaniana de Manganum metallicum (MnM-31CH) y de $65 \%$ en las plantas tratadas con dinamización homeopática 3 Centesimal Hahnemaniana de Magnesium-manganum phosphoricum (MaMnP$3 \mathrm{CH})$, comparado con las plantas que recibieron agua destilada (AD) como tratamiento control (Figura 1A). equipment (LCpro-SD Portable Photosynthesis System) that included a broad-leaf camera (ADC, Hoddesdon, Herts, UK). Chlorophyll determination was performed on each plant taking samples from fresh and totally expanded leaves, previously cleaned with deionized water to remove any environmental contamination on their surface. For the extraction of photosynthetic pigments, $1 \mathrm{~g}$ of fresh material per sample was taken, which were ground in a mortar with $90 \%$ acetone, and subsequently left to settle in darkness for $72 \mathrm{~h}$ before measuring absorbance, which was read at 663 and $645 \mathrm{~nm}$ in wavelength with an UV/Visible spectrophotometer (Pye Unicam SP6550, UK).

At 50 days after sowing, foliar area was assessed $\left(\mathrm{cm}^{2}\right)$ with a measuring equipment (Li-Cor ${ }^{\circledR}$, modelLI-3000A, series PAM 1701-USA). Fresh biomass (g) was determined by root (BFR), stem (BFT) and leaf $(\mathrm{BFH})$ weight in an analytical balance (Mettler Toledo $^{\circledR}$, model AG204 USA). To obtain dry biomass, all the fresh material was placed separately (root, stem, and leaf) in paper bags and introduced in a drying stove (Shel-Lab ${ }^{\circledR}$, model FX-5, series-1000203) at $70{ }^{\circ} \mathrm{C}$ for $72 \mathrm{~h}$ for total dehydration. At the end of this process, they were weighed in an analytical balance (Mettler Toledo ${ }^{\circledR}$, AG204) expressing values in grams. An analysis of variance (ANOVA) was performed, and Tukey's HSD multiple comparison of means was applied when significant differences $P \leq 0.05$ were found among treatments, using Statistica v. 10.0 program for Windows (StatSoft, Inc, 2011).

\section{RESULTS AND DISCUSSION}

The results of the total chlorophyll and photosynthetic rate analyses showed significant differences $(P=0.02)$ among treatments with increase in photosynthetic pigment concentration in plants that received homeopathic treatments. This difference was higher than $90 \%$ in plants that received Manganum metallicum 31 Centesimal Hahnemanian dynamization (MnM-31CH) and $65 \%$ in those treated with Magnesium-manganum phosphoricum 3 Centesimal Hahnemanian dynamization (MaMnP$3 \mathrm{CH})$, compared to those that received distilled water $(\mathrm{AD})$ as control treatment (Figure 1A). 

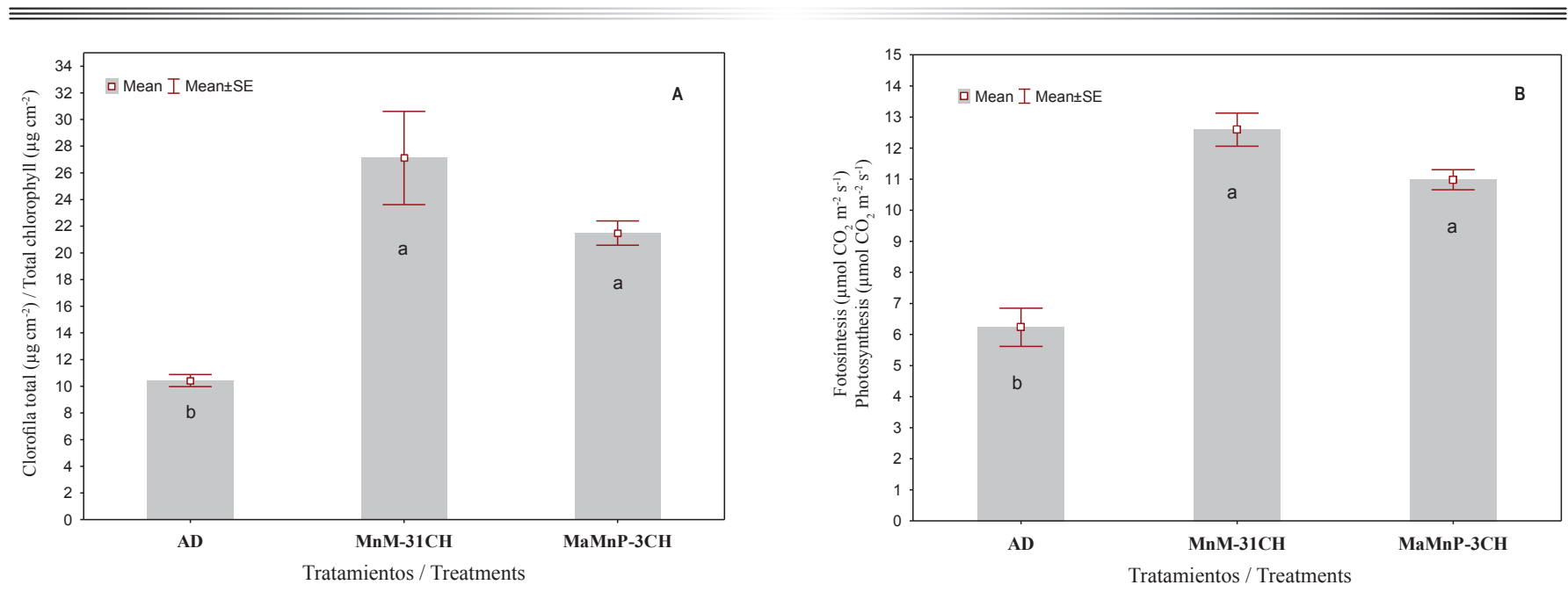

Figura 1. Efecto de los medicamentos homeopáticos en el porcentaje de germinación de Salicornia bigelovii. Letras distintas muestran diferencias estadísticas significativas $(P=0.05)$.

Figure 1. Effect of homeopathic medicines on the germination percentage of Salicornia bigelovii. Different letters show significant statistical differences $(P=0.05)$.

La tasa fotosintética de las plantas tratadas con medicamentos homeopáticos se incrementó en $71.6 \%$ para $\mathrm{MnM}-31 \mathrm{CH}$ y en $42.85 \%$ para MaMnP$3 \mathrm{CH}$, en comparación con el tratamiento control $\mathrm{AD}$ (Figura 1B).

Si se aplica un criterio tradicional, estos resultados pueden ser explicados por la presencia de nanopartículas del ingrediente activo en el medicamento homeopático aplicado, que pueden incidir de forma directa en los procesos fisiológicos de las plantas, estimulando su crecimientoy desarrollo, inclusoen condicionesadversas (Mazón et al., 2018). En el caso del tratamiento MnM$31 \mathrm{CH}$, su ingrediente activo en el concentrado inicial o "tintura madre" de la cual procede, es el manganeso metálico. Este elemento es, después del hierro, uno de los micronutrientes más demandado por las plantas porque contribuye al funcionamiento de varios procesos biológicos incluyendo la fotosíntesis, la respiración y la asimilación de nitrógeno, además de tener un rol importante en la síntesis de proteínas (Teixeira et al., 2004; Prato y Gómez, 2014). En cambio, el tratamiento $\mathrm{MaMnP}-3 \mathrm{CH}$ incluye manganeso y también magnesio, que juega un papel importante en la formación de la molécula de clorofila y favorece la concentración de pigmentos verdes (Cakmak y Yazici, 2010). A mayor concentración de pigmentos fotosintéticos existe mayor absorción de energía luminosa, y esto a su vez, se traduce en mayor eficiencia del proceso fotosintético,
The photosynthetic rate of the plants treated with homeopathic medicines increased in 71.6\% for MnM$31 \mathrm{CH}$ and in $42.85 \%$ for $\mathrm{MaMnP}-3 \mathrm{CH}$, compared with the $\mathrm{AD}$ control treatment (Figure 1B).

If a traditional criterium is applied, these results could be explained by the presence of nanoparticles of the active ingredient in the homeopathic medicine applied, which could have a bearing on plant physiological processes, stimulating their growth and development even in adverse conditions (Mazón et al., 2018). In the case of the MnM-31CH treatment, its active ingredient in the initial concentration or "mother tincture" from which it originated, is metallic manganese. These element is, after iron, one of the most demanded micronutrients by plants because it contributes to the function of various biological processes, including photosynthesis, respiration and nitrogen assimilation besides having an important role in protein synthesis (Teixeira et al., 2004; Prato and Gómez, 2014). On the other hand, the MaMnP-3CH includes manganese and also magnesium, which plays an important role in forming chlorophyll molecules and favor green pigment concentration (Cakmak and Yazici, 2010). At a greater photosynthetic pigment concentration, a greater absorption of luminous energy will exist, which in turn translates into greater efficiency of the photosynthetic process since more 
ya que se genera mayor energía química que garantiza mayor acumulación de biomasa y facilita la producción de plantas más vigorosas (Guo et al., 2016).

Tal como se aprecia en la Figura 2, se registraron diferencias significativas entre tratamientos para el área foliar $(P=0.036)$ y la transpiración $(P=0.04)$, notándose un incremento del área foliar cuando las plantas de frijol fueron asperjadas con las dinamizaciones homeopáticas (MnM-31CH y $\mathrm{MaMnP}-3 \mathrm{CH})$. La transpiración en plantas tratadas con MnM-31CH alcanzó el mayor valor, seguido de las que recibieron $\mathrm{MaMnP}-3 \mathrm{CH}$ y del tratamiento control, con menor transpiración. Tales resultados sugieren que las dinamizaciones homeopáticas empleadas estimularon la división y elongación celular en las hojas de las plantas tratadas, logrando de esta manera mayor área foliar. Esta respuesta puede ser asociada a la acción directa de los ingredientes activos de los medicamentos homeopáticos empleados, que contienen $\mathrm{Mn}^{2+} \mathrm{y} \mathrm{Mg}^{+2}$, estos juegan un rol importante en el proceso de fotosíntesis, en la síntesis de proteínas y en la asimilación del nitrógeno (Guo et al., 2016). Se puede asumir que la transpiración fue mayor en las plantas que recibieron MnM-31CH y MaMnP-3CH debido a una mayor disponibilidad de líquidos en el interior de los tejidos, que pudiera estar relacionada con un incremento en la biomasa fresca de la raíz (Cuadro 1). Según Niu et al. (2014) el manganeso,

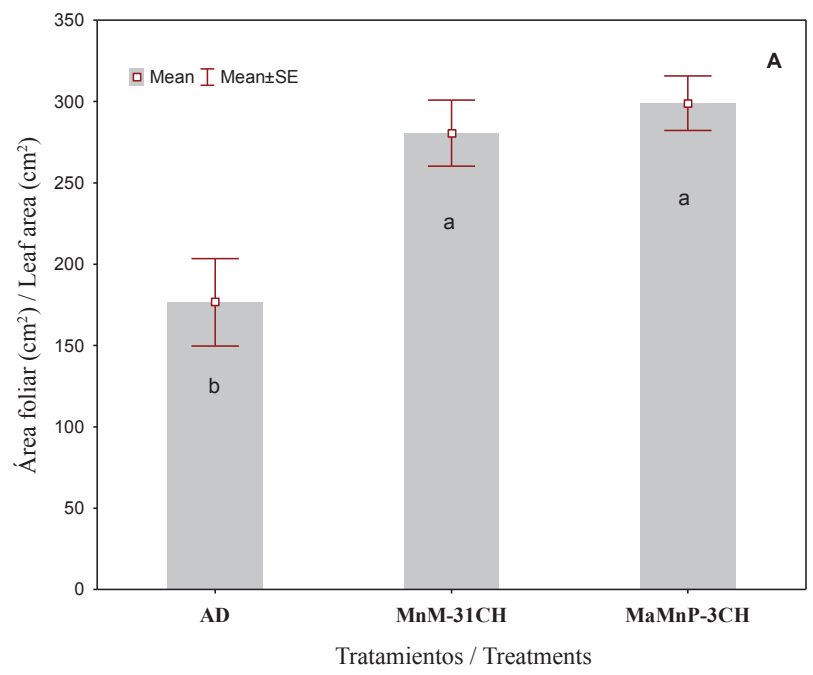

chemical energy is generated guaranteeing greater biomass accumulation and facilitating more vigorous plant production (Guo et al., 2016).

As Figure 2 shows, significant differences were recorded among treatments for the foliar area $(P=0.036)$ and transpiration $(P=0.04)$, noting an increase in foliar area when bean plants were sprayed with the homeopathic medicines (MnM-31CH and $\mathrm{MaMnP}-3 \mathrm{CH})$. The transpiration in treated plants with MnM-31CH reached the greatest value, followed by those that received $\mathrm{MaMnP}-3 \mathrm{CH}$ and the control treatments with less transpiration. Such results suggested that the homeopathic dynamizations used stimulated cell division and elongation in leaves of the treated plants, achieving in this manner greater foliar area with less transpiration. This response could have been associated to the direct action of the active ingredients of the homeopathic medicines used, which contained $\mathrm{Mn}^{2+}$ and $\mathrm{Mg}^{+2}$ that play an important role in protein synthesis and nitrogen assimilation (Guo et al., 2016). We can assume that transpiration was greater in plants that received MnM-31CH and MaMnP$3 \mathrm{CH}$ because of a greater availability of liquids in the inner part of the tissues, which could be related to an increase in fresh root biomass (Table 1). According to Niu et al. (2014) manganese, included as homeopathic ingredient in $\mathrm{MnM}-31 \mathrm{CH}$ and $\mathrm{MaMnP}-3 \mathrm{CH}$, boosted

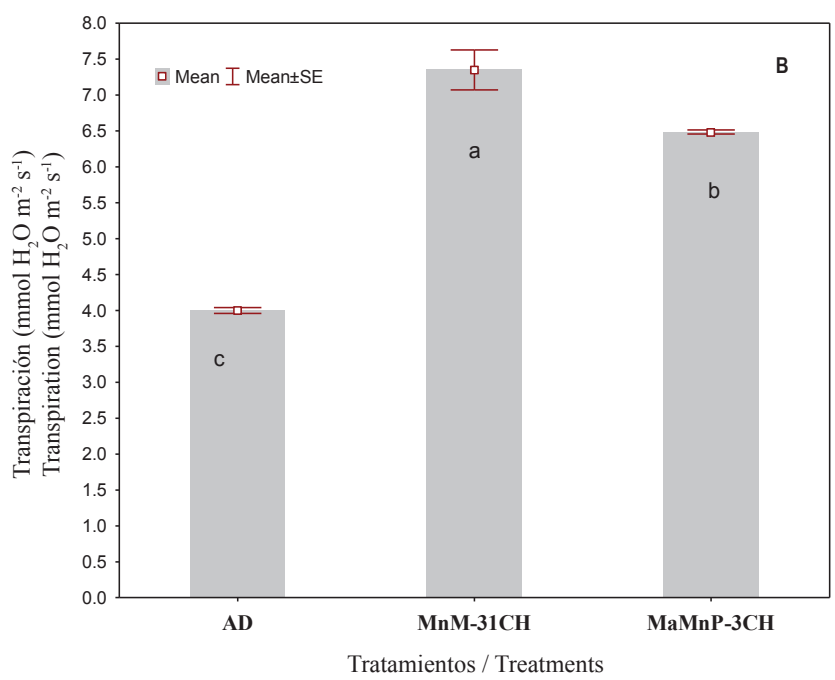

Figura 2. Efecto de medicamentos homeopáticos en el área foliar (A) y en la transpiración (B) de Vigna unguiculata L., Walp. Letras distintas muestran diferencias estadísticas significativas (Tukey HSD, $P=0.05$ ).

Figure 2. Effect of homeopathic medicines in the foliar area (A) and in the transpiration (B) of Vigna unguiculata L., Walp. Different letters show significant statistical differences (Tukey's HSD, $P=0.05$ ). 
incluido como ingrediente homeopatizado en MnM$31 \mathrm{CH}$ y MaMnP-3CH, fomenta la formación de raíces laterales, permitiendo de esta manera que las plantas logren mayor absorción de agua y de nutrientes dada su posibilidad incrementada de explorar mayor área de suelo, lo que beneficia su crecimiento y desarrollo.

El análisis de resultados mostró diferencias significativas entre tratamientos, para biomasa fresca y seca de raíz, tallo y hojas (Cuadro 1), y se observó un incremento del 111.2 y $96.36 \%$ respectivamente, en la variable BFR para plantas tratadas con MnM$31 \mathrm{CH}$ y MaMnP-3CH, comparado con las no tratadas homeopáticamente (AD). El incremento para la variable BSR en las plantas tratadas con homeopatía fue superior a las del control no tratadas (AD), evidenciándose una mejor respuesta cuando las plantas fueron tratadas con manganeso metálico homeopatizado (MnM-31CH). No se observaron diferencias significativas entre los tratamientos homeopáticos (MnM-31CH y MaMnP$3 \mathrm{CH}$ ) con respecto a BFT y BST. Sin embargo, ambos tratamientos mostraron diferencias significativas $(P \leq 0.05)$ en estas variables, con respecto al control (Cuadro 1). La biomasa fresca de hojas fue significativamente superior en las plantas tratadas con los medicamentos homeopáticos, logrando un incremento de $65.5 \%$ para MaMnP-3CH, con respecto al tratamiento control AD. Para la variable $\mathrm{BSH}$ la respuesta fue similar, pero con un aumento del $56 \%$ en las plantas que recibieron MaMnP-3CH. El incremento en biomasa fresca y seca observado en las plantas tratadas con manganeso metálico homeopatizado (MnM-31CH) y con fosfato de magnesio-mangneso homeopatizado (MaMnP-3CH), confirma una respuesta positiva al tratamiento, ya que el magnesio lateral root formation, allowing plants to achieve greater water and nutrient absorption given it increased the possibility of exploring greater soil area, which benefitted its growth and development.

The analysis of the results showed significant differences among treatments for fresh and dry root, stem and leaf biomass (Table 1), observing and increase of 111.2 and $96.36 \%$ respectively, in the BFR variable for plants treated with MnM-31CH and MaMnP-3CH, compared with those not treated homeopathically (AD). The increase for the BSR variable in plants treated with homeopathy was higher than in those not treated in the control group (AD) making a better response more evident when plants were treated with homeopathic metallic manganese (MnM-31CH). No significant differences were observed among the homeopathic treatments (MnM-31CH and MaMnP$3 \mathrm{CH})$ with respect to BFT and BST. Nonetheless, both treatments showed significant differences $(P \leq$ $0.05)$ in these variables with respect to the control group (Table 1). Fresh leaf biomass was significantly higher in plants treated with homeopathic medicine, reaching an increase of $65.5 \%$ for MaMnP-3CH, with respect to the control $\mathrm{AD}$ treatment. For the $\mathrm{BSH}$ the response was similar but with an increase of $56 \%$ in plants that received MaMnP-3CH. The increase in fresh and dry biomass observed in plants treated with homeopathic metallic manganese (MnM-31CH) and homeopathic magnesium-manganese phosphate (MaMnP-3CH), confirmed a positive response to the treatments since magnesium and manganese were key elements during the development of the biological

Cuadro 1. Efecto de los medicamentos homeopáticos en la producción de biomasa de Salicornia bigelovii.

Table 1. Effect of homeopathic medicines on the biomass production of Salicornia bigelovii.

\begin{tabular}{|c|c|c|c|c|}
\hline Tratamientos / Treatments & BFPA & BSPA & BFR & BSR \\
\hline & \multicolumn{4}{|c|}{ 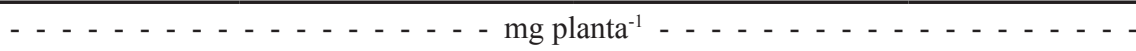 } \\
\hline $\mathrm{AD}$ & $0.132 \mathrm{c}$ & $0.014 \mathrm{~b}$ & $0.0046 \mathrm{c}$ & $0.0010 \mathrm{c}$ \\
\hline $\mathrm{NaM} 7 \mathrm{CH}$ & $0.232 \mathrm{a}$ & $0.024 \mathrm{a}$ & $0.087 \mathrm{a}$ & $0.0155 \mathrm{a}$ \\
\hline $\mathrm{PhA} 13 \mathrm{CH}$ & $0.229 \mathrm{a}$ & $0.020 \mathrm{ab}$ & $0.074 \mathrm{ab}$ & $0.0049 b$ \\
\hline $\mathrm{NaM} 31 \mathrm{CH}$ & $0.188 \mathrm{~b}$ & $0.018 \mathrm{ab}$ & $0.054 b$ & $0.0011 \mathrm{c}$ \\
\hline
\end{tabular}

$\overline{\mathrm{BFPA}}$ = biomasa fresca de parte aérea; BSPA = biomasa seca parte aérea; $\mathrm{BFR}=$ biomasa fresca de radícula; $\mathrm{BSR}=$ biomasa seca de radícula. Valores promedios con literales diferentes en una misma columna difieren estadísticamente (Tukey HSD, $P=0.05$ ).

$\mathrm{BFPA}=$ fresh biomass of aerial part; BSPA = dry biomass aerial part; $\mathrm{BFR}=$ fresh radicle biomass; $\mathrm{BSR}=$ dry radicle biomass. Average values with different literals in the same column differ statistically (Tukey HSD, $P=0.05$ ). 
y el manganeso son elementos clave durante el desarrollo de los procesos biológicos responsables de la producción de biomasa, tales como fotosíntesis, respiración y síntesis de proteínas (Ceppi et al., 2012).

Otros autores obtuvieron resultados similares en el cultivo del frijol común Phaseolus vulgaris en materia de producción de biomasa, al aplicar preparados homeopáticos cuyos ingredientes activos presentan similar acción en los indicadores fisiológicos de las plantas tratadas (Ruiz et al., 1997). En el cultivo de Allium fistolosum se observó un incremento significativo en el peso fresco, cuando las plantas fueron tratadas con medicamentos homeopáticos (Sánchez y Meneses, 2011). Similar resultado fue observado por Mazón-Suástegui et al. (2018) al aplicar Natrum muriaticum $7 \mathrm{CH}$ y $13 \mathrm{CH}$ al cultivo de albahaca Ocimum basilicum y obtener un incremento en la biomasa aun cuando las plantas fueron sometidas a estrés por $\mathrm{NaCl}$. Los resultados expuestos en la presente investigación demuestran que la homeopatía agrícola es una alternativa viable, con potencial para lograr más producción biológica, principalmente en la agricultura orgánica del futuro.

\section{CONCLUSIONES}

Los medicamentos homeopáticos aplicados incrementan significativamente la tasa fotosintética, clorofila total, área foliar, transpiración y biomasa fresca y seca de raíz, tallo y hojas en plantas de frijol Yorimón ( $V$. unguiculata) variedad Paceña. La mejor respuesta (incremento de $111.2 \%$ en BFR), se logró con el tratamiento basado en una dinamización homeopática 31 centesimal de manganeso metálico (MnM-31CH). Estos resultados señalan que la homeopatía agrícola puede ser una alternativa viable y de bajo costo para incrementar eco-amigablemente la producción de biomasa y la rentabilidad financiera del cultivo de $V$. unguiculata, con un impacto positivo en el sector agrícola latinoamericano.

\section{AGRADECIMIENTOS}

El estudio fue financiado por el Fondo Sectorial de Investigación para la Educación de México, proyecto Ciencia Básica CONACYT No. 258282 "Evaluación experimental de homeopatía y nuevos probióticos en el cultivo de moluscos, crustáceos y peces de interés comercial", bajo la responsabilidad académica de processes responsible for biomass productions, such as photosynthesis, respiration and protein synthesis (Ceppi et al., 2012).

Other authors have obtained similar results in the common bean Phaseolus vulgaris cultivation in biomass production when they have applied homeopathic medicines whose active ingredients have shown similar action in the physiological markers of the plants treated (Ruiz et al., 1997). In the cultivation of Allium fistolosum a significant increase was observed in fresh weight when plants were treated with homeopathic medicines (Sánchez and Meneses 2011). Similar results were observed by Mazón-Suástegui et al. (2018) when Natrum muriaticum $7 \mathrm{CH}$ and $13 \mathrm{CH}$ were applied to basil Ocimum basilicum cultivation obtaining and increase in biomass although plants were subjected to stress by $\mathrm{NaCl}$. The results set out in this research demonstrated that agricultural homeopathy is a viable alternative with the potential of achieving more biological production, mainly in future organic agriculture.

\section{CONCLUSIONS}

The two homeopathic medicines applied increased photosynthetic rate, total chlorophyll, foliar area, transpiration and fresh and dry root, stem, and leaf biomass significantly in "Yorimon" cowpea bean (V. unguiculata) variety Paceña. The best response (increase of $111.2 \%$ in BFR) was achieved with the treatment based on a high homeopathic dynamization (31 Centesimal Hahnemanian dynamization) of metallic manganese (MnM-31CH). These results confirmed that agricultural homeopathy can be a low cost and viable alternative to increase eco-friendly biomass production and financial feasibility of $V$. unguiculate cultivation with a positive impact on Latin American agricultural sector.

\section{ACKNOWLEDGMENTS}

This study was financed by the Fondo Sectorial de Investigación para la Educación de México [Sectorial Research Fund for Education], Project Ciencia Básica CONACYT No. 258282 "Evaluación experimental de homeopatía y nuevos probióticos en el cultivo de moluscos, crustáceos y peces de interés comercial" [Experimental assessment of homeopathy 
JMMS. Se agradece el apoyo técnico de la MC. Lidia Hirales-Lucero y el técnico Pedro Luna-García.

-Fin de la versión en español-

\section{REFERENCIAS / REFERENCES}

Bolaños E., A., O. Díaz, G. Mondragón y L. M. Serrano. 2009. Efectos de la densidad y distribución del frijol (Phaseolus vulgaris) sobre la maleza y período crítico de competencia. pp. 449-452. In: I. Sousa, M. Calha, I. Moreira, L. Rodrigues, J. Portugal, T. Vasconcelos (eds.). Vol. 1. Herbología e biodiversidade numa agricultura sustentável. Actas XII Congresso da SEMh, XIX Congresso da ALAM, II Congresso da IBCM. Lisboa, Portugal. ISBN: 978-972-8669-44-7.

Cakmak, I. and A. M. Yazici. 2010. Magnesium: Forgotten element in crop production. Better Crops 94: 23-25.

Calero Hurtado, A., E. Quintero Rodríguez, Y. Pérez Díaz, D. Olivera Viciedo, K. Peña Calzada y J. Jiménez Hernández. 2019. Efecto entre microorganismos eficientes y fitomas-e en el incremento agroproductivo del frijol. Biotecnol. Sector Agrop. Agroind. 17: 25-33. doi: http://dx.doi.org/10.18684/ bsaa.v17n1.1201.

Ceppi, M. G., A. Oukarroum, N. Çiçek, R. J. Strasser, and G. Schansker. 2012. The IP amplitude of the fluorescence rise OJIP is sensitive to changes in the photosystem I content of leaves: A study on plants exposed to magnesium and sulfate deficiencies, drought stress and salt stress. Physiol. Plant 144: 277-288. doi: 10.1111/j.1399-3054.2011.01549.x.

Debouck, D. and R. Hidalgo. 1985. Morfología de la planta de fríjol común. pp. 7-41. In: M. López, F. Fernández y A. van Sochoonhoven (comp.). Frijol: investigación y producción. Programa de las Naciones Unidas (PNUD); Centro Internacional de Agricultura Tropical (CIAT). Cali, Colombia.

Estrada Prado, W., L. Chávez Suárez, E. Jerez Mompie, M. C. Nápoles García, Y. C. Maceo Ramos y C. Cordoví Domínguez. 2018. Efecto del Azofert ${ }^{\circledR}$ en plantas de frijol (Phaseolus vulgaris L.) sometidas a dos regímenes de riego. Ctro. Agríc. 45: 20-26.

García R., H. 2005. Cocina prehispánica mexicana; la comida de los antiguos mexicanos. Panorama, México, D. F. ISBN: 96838-0258-3.

Guo, W., N. Hussain, Z. Liang, and D. Yang. 2016. Magnesium deficiency in plants: An urgent problem. Crop J. 4. 83-91. doi: https://doi.org/10.1016/j.cj.2015.11.003.

Hillocks, R. J., C. S. Madata, R. Chirwa, E. M. Minja, and S. Msolla. 2006. Phaseolus bean improvement in Tanzania. 19592005. Euphytica 150: 215-231. doi: https://doi.org/10.1007/ s10681-006-9112-9.

ISTA (International Seed Testing Association). 2010. Rules proposals for the International Rules for Seed Testing 2010 Edition. OM Rules Proposals for the International Rules for Seed Testing 2010 Edition.doc. Approved by ECOM Decision. No.498. Bassersdorf, Switzerland. and new probiotics in mollusks, crustaceans and fish of commercial interest], under the academic responsibility of JMMS. The authors thank the technical support of Lidia Hirales-Lucero and Pedro Luna-García; Diana Fischer for translation and editorial services.

-End of english version-

Mazón-Suástegui, J. M., B. Murillo-Amador, D. Batista-Sánchez, Y. Agüero-Fernández, M. R. García-Bernal, and C. M. OjedaSilvera. 2018. Natrum muriaticum as an attenuant of NaClsalinity in basil (Ocimum basilicum L.). Nova Scientia 10: 120-136. doi: 10.21640/ns.v10i21.1423.

Mazón-Suástegui, J. M., C. M. Ojeda-Silvera, M. García-Bernal, M. A. Avilés-Quevedo, F. Abasolo-Pacheco, D. Batista-Sánchez, D. Tovar-Ramírez, F. Arcos-Ortega, B. Murillo-Amador, A. Nieto-Garibay, Y. Ferrer-Sánchez, R. M. Morelos-Castro, A. Alvarado-Mendoza, M. Díaz-Díaz, and B. Bonilla-Montalvan. 2019. Agricultural homeopathy: A new insights into organic's. IntechOpen Books. doi: 10.5772/intechopen.84482.

Meneses Moreno, N. 2017. Agrohomeopatía como alternativa a los agroquímicos. Rev. Méd. Homeop. 10: 9-13. doi: https://doi. org/10.1016/j.homeo.2017.04.004.

Moreno Lorenzo, X. A., L. Lobelle Muñiz y J. González Ramírez. 2018. Efecto de los bioestimulantes Biobras 16 y Quitomax sobre el cultivo del frijol (Phaseolus vulgaris L.) variedad Delicias-364' en la agricultura suburbana de Aguada de Pasajeros. Rev. Cient. Agroecosist. 6: 151-160.

Muhamba, T. and S. Nchimbi. 2010. Diversity of common bean (Phaseolus vulgaris L.) genotypes in iron and zinc contents under screenhouse conditions. Afr. J. Agric. Res. 5: 738-747. doi: 10.5897/AJAR10.304.

Niu, Y., R. Chai, L. Liu, G. Jin, M. Liu, C. Tang, and Y. Zhang 2014. Magnesium availability regulates the development of root hairs in Arabidopsis thaliana (L.) Heynh, Plant Cell. Environ. 37: 2795-2813. doi: 10.1111/pce.12362.

Oliveira-Batista, J. S., A. J. Maia, K. R. F. Schwan-Estrada, C. M. Bonato, S. M. T. P. G. Carneiro, and M. H. S. Picoli. 2014. Activation of biochemical defense mechanisms in bean plants for homeopathic preparations. Afr. J. Agric. Res. Lagos 9: 971981. doi: 10.5897/AJAR2013.8248.

Prato S., A. I y M. I. Gómez. 2014. Aplicación líquida edáfica y foliar de manganeso en espinaca (Spinacia oleraceae L.) cultivada en sustrato vermicompost. Rev. Colomb. Cienc. Hortíc. 8: 262-271. doi: 10.17584/rcch.2014v8i2.3219.

Rivero Herrada, M., R. R. Gaibor Fernández, J. J. Reyes Pérez, W. Mozena Leandro y E. Petrônio de Brito Ferreira. 2016. Abonos verdes y su influencia en el frijol (Phaseolus vulgaris L.) en sistema agroecológico. Ctro. Agríc. 43: 42-48.

Ruiz, E., I. Castro y P. Curtis. 1997. Uso del barbasco (Dioscorea villosa) en dinamizaciones homeopáticas como bio-regulador 
de crecimiento de crecimiento del frijol (Phaseolus vulgaris). Cuadernos de Centros Regionales. Chapingo, México.

Samperio R., G. 1997. Hidroponía básica. Diana. México, D. F.

Sánchez S., J. L. y N. Meneses Moreno. 2011. Efecto de cinco medicamentos homeopáticos en la producción de peso fresco, en cebollín (Allium fistolosum). Disponible en: http://www. comenius.edu.mx/Cinco_medicamentos_homeop_ticos_en_ Ceboll_n.pdf (Consulta: febrero 11, 2019).

SSA (Secretaría de Salud). 2015. Farmacopea homeopática de los Estados Unidos Mexicanos. FEUM-SSA. Biblioteca Nacional de México 615.532-scdd21. ISBN: 978-607-460-509-9.

SIAP (Servicio de Información Agroalimentaria y Pesquera). 2018. Anuario Estadístico de la Producción Agrícola. Disponible: https://nube.siap.gob.mx/cierreagricola/ (Consulta: diciembre 04, 2018).

StatSoft Inc. 2011. Statistica. System reference. StatSoft, Inc. Tulsa, OK, USA.

Teixeira, I., A. Borém, G. Araújo, and R. Fontes. 2004. Manganese and zinc leaf application on common bean grown on a soil. Sci. Agric. 61: 77-81. doi: http://dx.doi.org/10.1590/S010390162004000100013.

Voysest Voysest, Oswaldo. 2000. Mejoramiento genético del frijol (Phaseolus vulgaris L.) : Legado de variedades de América Latina 1930-1999. Publicación CIAT no. 321. Centro Internacional de Agricultura Tropical (CIAT) Cali, Colombia. 